ORIGINAL ARTICLE

\title{
Analysis of students' foot pressure distribution on the ground, as well as their body balance before and after exercise
}

\author{
Jarosław Jaszczur-Nowicki ${ }^{1 \mathrm{ACDE}}$, Joanna Bukowska ${ }^{1 \mathrm{BCD}}$, Dariusz Kruczkowski ${ }^{2 \mathrm{CE}}$, Michał Spieszny ${ }^{3 \mathrm{DE}}$, \\ Magdalena Pieniążek ${ }^{4 C D}$, Grzegorz Mańko ${ }^{5 \mathrm{CD}}$ \\ ${ }^{1}$ University of Warmia and Masuria in Olsztyn, Poland \\ ${ }^{2}$ Elblag University of Humanities and Economy in Elblag, Poland \\ ${ }^{3}$ University of Physical Education, Kraków, Poland \\ ${ }^{4}$ Bronistaw Czech University School of Physical Education in Kraków, Poland \\ ${ }^{5}$ Medical College (Collegium Medicum) of the Jagiellonian University in Kraków, Poland
}

Authors' Contribution: A - Study design; B - Data collection; C - Statistical analysis; D - Manuscript Preparation; E - Funds Collection

\begin{abstract}
Purpose: $\quad$ The article presents the results of analyses of students' foot pressure distribution on the ground, as well as their body balance before and after exercise (Harvard Step Test). The aim of the paper was to carry out a comparative analysis of foot pressure distribution on the ground, as well as assess the degree of body balance before and after exercise. With that purpose in view, the following research hypothesis was formulated: in the students participating in the study, the distribution of foot pressure on the ground and the degree of body balance differ significantly after physical effort compared with the at-rest conditions.

Material: $\quad$ The study encompassed $n=48$ students, including 37 women and 11 men. The tests were carried out using such tools as: an EPS/R1 podobarographic mat and the impedance methods - i.e. the InBody 270 body composition analyser. An analysis was performed for the parameters concerning body composition, the distribution of foot pressure on the ground, and the level of body balance.

Results: $\quad$ The results obtained revealed statistically significant differences in the physiological parameters of foot arching and the functional efficiency of the body balance system under different measurement conditions that reflected the impact of effort stimuli.

Conclusions: Significant differences reflecting the impact of the effort stimuli were expected to be achieved during the mathematical analysis of the results of podobarographic tests that allow for the assessment of the physiological parameters of foot arching and the functional efficiency of the body balance system under different measurement conditions. The authors' assumption was mathematically and statistically confirmed by significant differences foe most of the parameters arising out of the possibilities offered by the research method applied. Comparative assessment unquestionably revealed a negative change in foot arching, as well as lower body posture stability in the female and male subjects, resulting from the physical exercise applied.

Keywords: foot, ground pressure, body balance, physical activity, students.
\end{abstract}

\section{Glossary:}

cop-dist - distance between extreme deflections of the body's centre of gravity,

cop-bars - surface of deflections of the body's centre of gravity,

1-bars - left foot deflection area,

p-bars - right foot deflection area,

cop-speed - deflections speed of body's centre of gravity, cop-lsf - ratio of the distance between extreme deflections to the deflection surface

\section{Introduction}

The concept that refers to all the movement activities of a human being is known as motority. This term can be used to define every single aspect related to human movement in space, as a result of changing the position of the body or its particular parts against each other. Motority may also be understood as the entirety of motor needs and behaviour as well as related conditions (c) Jarosław Jaszczur-Nowicki, Joanna Bukowska,

Dariusz Kruczkowski, Michał Spieszny, Magdalena Pieniążek,

Grzegorz Mańko, 2020

doi:10.15561/20755279.2020.0402 and manifestations $[1,2]$. Too little or complete lack of physical activity leads to regression in the level of motor abilities. Therefore, human beings are able to train their motor abilities through regular physical activity [3].

During phylogeny, human beings freed their upper limbs from the need to support their bodies, thus becoming bipedal creatures. As a result, however, they constantly need to strive to maintain a 'safe' body posture under static and dynamic conditions [4]. In this context, the foot is the key element that allows for spatial balancing of body position under static conditions. Feet also act as a kind of driving mechanism that propels the body during locomotion. Proper foot function is determined by their morphological structure, especially by the correct development of the transverse and longitudinal arches, which guarantee proper shape of the feet. Elastic and distinctly shaped arches have protective and shockabsorbing functions for other systems of the body, at the same time supporting the entire body $[1,5]$.

An active and stable foot is the one which can shortly adapt and react to new and unpredictable situations, along with body posture control in a unipedal position. 
These are the basic skills that make it possible to properly control the body posture during loss of balance.

The development of the longitudinal arch of the foot is the effect of evolution and adaptation to the bipedal position $[1,6]$. This would seem to indicate that feet undergo development throughout our lives on an individual basis, depending on our lifestyle, occupation and type of footwear [7]. The dynamic development of the foot arch begins as the feet start to push against a fixed surface while walking, i.e. at the end of the first 12 months $[8,9]$. The quickest development of the foot arch can be observed in children between 2 and 6 years old. Some authors maintain that the arches keep developing - though clearly less dynamically - up to the age of 9 or even 13 [10]. This has an effect on the development of body balance. It involves analysis of the ensuing ground reactive forces generated by foot pressure while standing. The manner of maintaining balance demonstrates the ability to coordinate movement [11].

Body balance can be developed depending on patients' age. In older children, the development dynamics of this ability may be partially affected by their height and body weight, even though relevant studies on individuals at different ages do not fully confirm this relationship. Agerelated changes in body balance control may also be determined by the development of our organ of vision, the vestibular system and the somatosensory system. Therefore, it is possible to note the relationship between this ability and age, because there is a strong link between the developmental and involution changes and the results of balance measurement [12].

Some researchers suggest that fatigue in the muscle groups of lower limbs may affect the balance function. Further findings demonstrate that fatigue in the extensors and flexors of the hip and knee joints, as well as in the muscles around the tarsal (ankle) joints, considerably reduces the balance function. Hip extensors play an important role in maintaining a standing position of the body, and unilateral fatigue of this group of muscles had an effect on the balance function. When a given individual falls backwards, the postural reflexes lead to bending and extension of the hip joint on the one side. It is an innate human reflex that involves stimulation of tactile receptors on the soles and proprioceptive sensations in the tarsal (ankle) joints in order to control posture. In such a situation, signals from the tactile receptors on the sole cause dorsal flexion, leading to body movements that prevent falling and keep a steady posture. While considering this reflex mechanism of body posture, there is an obvious risk of falling in the event of difficulties with dorsal flexion of the ankle or hip extension. Research suggests that fatigue in the extensors of the hip joint is associated with decreased body balance function in healthy young adults. Therefore, it would be reasonable to implement a programme of balance training that concentrates on strengthening hip extensors $[13,14]$.

Such tests can be performed through static stabilography that deals with the registration of involuntary changes in the point where the resultant pressure forces of an individual standing freely on a stabilographic platform act on the ground. Such registration helps to obtain the movement trajectory for this point (referred to as $\mathrm{COP}-$ Centre of Pressure in the literature) [15]. A stabilographic platform is a trusted and recognised method for assessing posture stability, increasingly used by researchers [16]. Therefore, this very method was applied to our own study.

Research hypothesis: in the student subjects, the distribution of foot pressure on the ground and the body balance differ significantly after exercise compared with the at-rest conditions.

Purpose: the aim of the paper was to carry out a comparative analysis of foot pressure distribution on the ground, as well as assess the degree of body balance before and after exercise.

\section{Material and Methods}

Participants. The study encompassed $\mathrm{n}=55$ students from the major of Tourism and Recreation, including 40 women and 15 men. During the research process, 7 individuals were excluded from the study (3 women and 4 men) after failing to complete the Harvard Step Test. Eventually, the study encompassed 48 individuals, including 37 women and 11 men. The basic somatic parameters in the female subjects were very close to each other (Table 1). Their average height was $169.41 \mathrm{~cm}$ and all had a similar body weight $(65.87 \mathrm{~kg})$. In the case of men, the average height was $176.82 \mathrm{~cm}$, while the average body weight $-70.91 \mathrm{~kg}$ (Table 2). All the subjects had current medical certificates allowing them to participate in the measurements. The study was approved by the Ethics Committee for Scientific Research of the University of Varmia and Masuria in Olsztyn (Decision No. 9/2018).

Procedure. The measurements were made during the summer semester of the academic year, i.e. in 2019, at the Human Motority Laboratory, Department of Tourism, Recreation and Ecology, Faculty of Environmental Sciences of the University of Warmia and Masuria in Olsztyn. The air temperature in the room was $22^{\circ} \mathrm{C}$.

Each subject was dressed in sportswear and stood barefoot on the Inbody 270 body composition analyser.

Table 1. Number characteristics of the female students participating in the study

\begin{tabular}{llllll}
\hline Variables & Average & Standard deviation & Median & Min. & Max. \\
\hline Age & 20.81 & 0.83 & 21.00 & 19.00 & 23.00 \\
Height $[\mathrm{cm}]$ & 169.41 & 7.12 & 170.00 & 155.00 & 183.00 \\
Weight $[\mathrm{kg}]$ & 65.87 & 8.82 & 64.50 & 44.20 & 107.40 \\
BMI (Body Mass Index) $[\mathrm{kg} / \mathrm{m} 2]$ & 22.87 & 2.89 & 22.50 & 17.90 & 33.90 \\
\hline
\end{tabular}


Table 2. Number characteristics of the male students participating in the study

\begin{tabular}{llllll}
\hline Variables & Average & Standard deviation & Median & Min. & Max. \\
\hline Age & 20.73 & 1.14 & 20.77 & 0.83 & 23.00 \\
Height $[\mathrm{cm}]$ & 176.82 & 6.58 & 169.70 & 7.12 & 183.00 \\
Weight $[\mathrm{kg}]$ & 70.91 & 11.12 & 65.19 & 8.82 & 107.40 \\
BMI (Body Mass Index) $[\mathrm{kg} / \mathrm{m} 2]$ & 22.64 & 3.08 & 23.70 & 17.90 & 28.80 \\
\hline
\end{tabular}

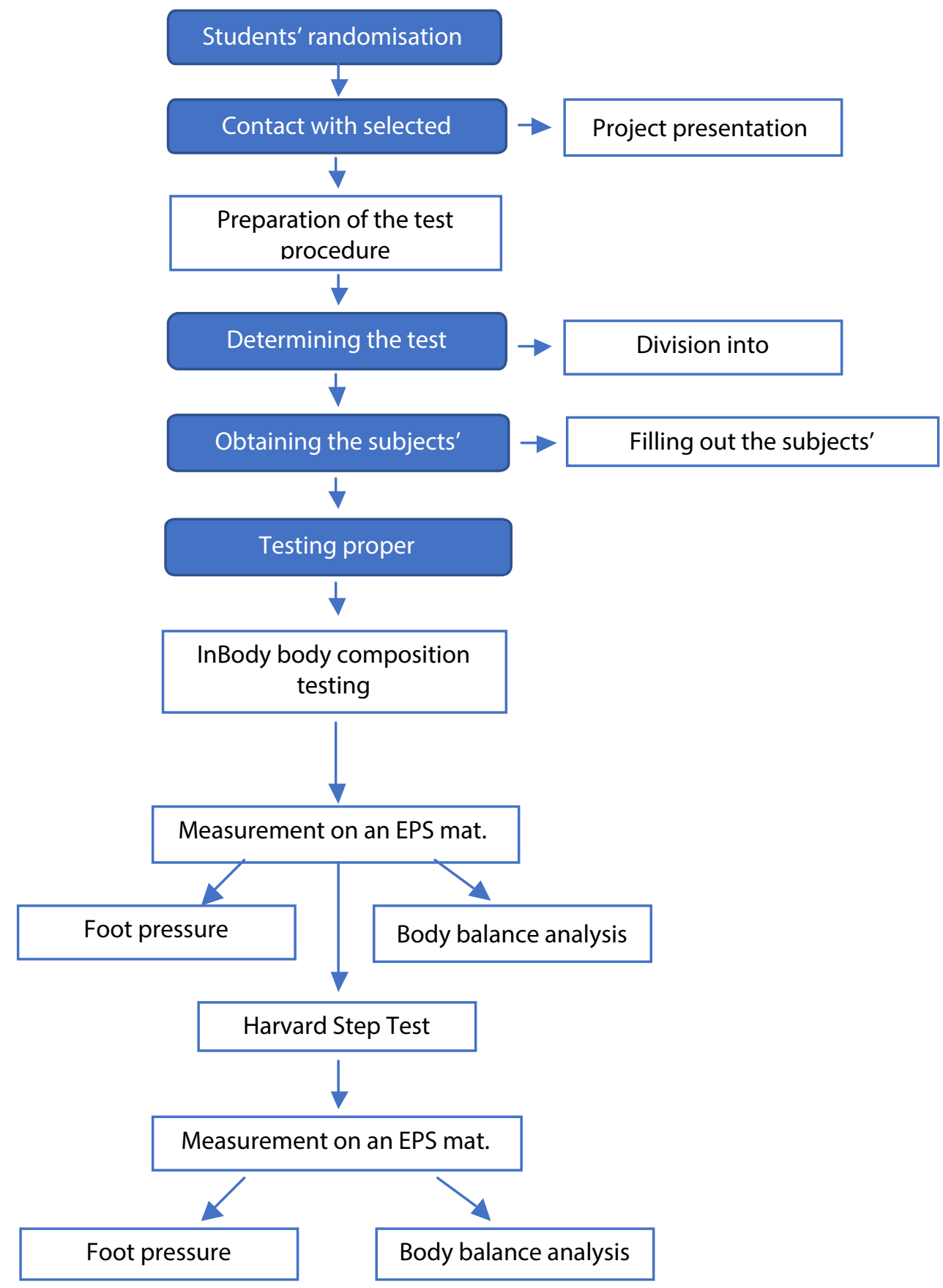

Fig. 1. Diagram of the test procedure

This device uses impedance with a frequency of 20, $100 \mathrm{kHz}$ and current intensity of $200 \mu \mathrm{A}$ to make measurements, thanks to the 8-point tetrapolar system of touch-sensitive electrodes ( 2 electrodes for the left foot, 2 for the right, 2 for the left hand, and 2 for the right). The subjects placed their feet and hands as shown by the instructor, and the test lasted for 15 seconds.

The tests proper were conducted using the E.P.S./R1 podobarographic mat. It is a diagnostic tool for assessing foot defects under static and dynamic conditions. It allows for evaluating the distribution of foot pressure on the ground and body balance. The mat is equipped 
with sensors that need 20 seconds to collect the relevant measurements and transfer them to the computer using the Biomech Studio software (Manual of the Biomech Studio 2.0 software).

Two measurement tests were carried out during the studies. Between the first and the second test, each subject received a form of an effort stimulus involving participation in the Harvard Step Test, i.e. a test of rhythmical climbing on a step of a specific height. One exercise cycle involved placing one (for example the left) foot on the step and joining the other (the right). Next, the subject put down the left foot on the ground and joined the right one. The exercise was performed with straight knee and hip joints both after ascending and descending from the step. Each subsequent cycle was started once the previous one was completed. The rhythm of ascending the step was fixed and uniform for the entire study group, amounting to 30 cycles per minute. The movement speed was determined using a metronome. The duration of the test and the height of the step depended on the subjects' sex. In the case of women, the test was 4 minutes long and the step was $46 \mathrm{~cm}$ high. The male test was longer and lasted for 5 minutes, and the step was $5 \mathrm{~cm}$ higher $(51 \mathrm{~cm})$.

\section{Statistical analysis}

In order to properly analyse the test results, use was made of the basic static functions whose symbols can be seen in the paper:

$\mathbf{M}$ - the arithmetic mean for numbers $a_{1}, a_{2}, \ldots, a_{n}$ the number determined by the following formula
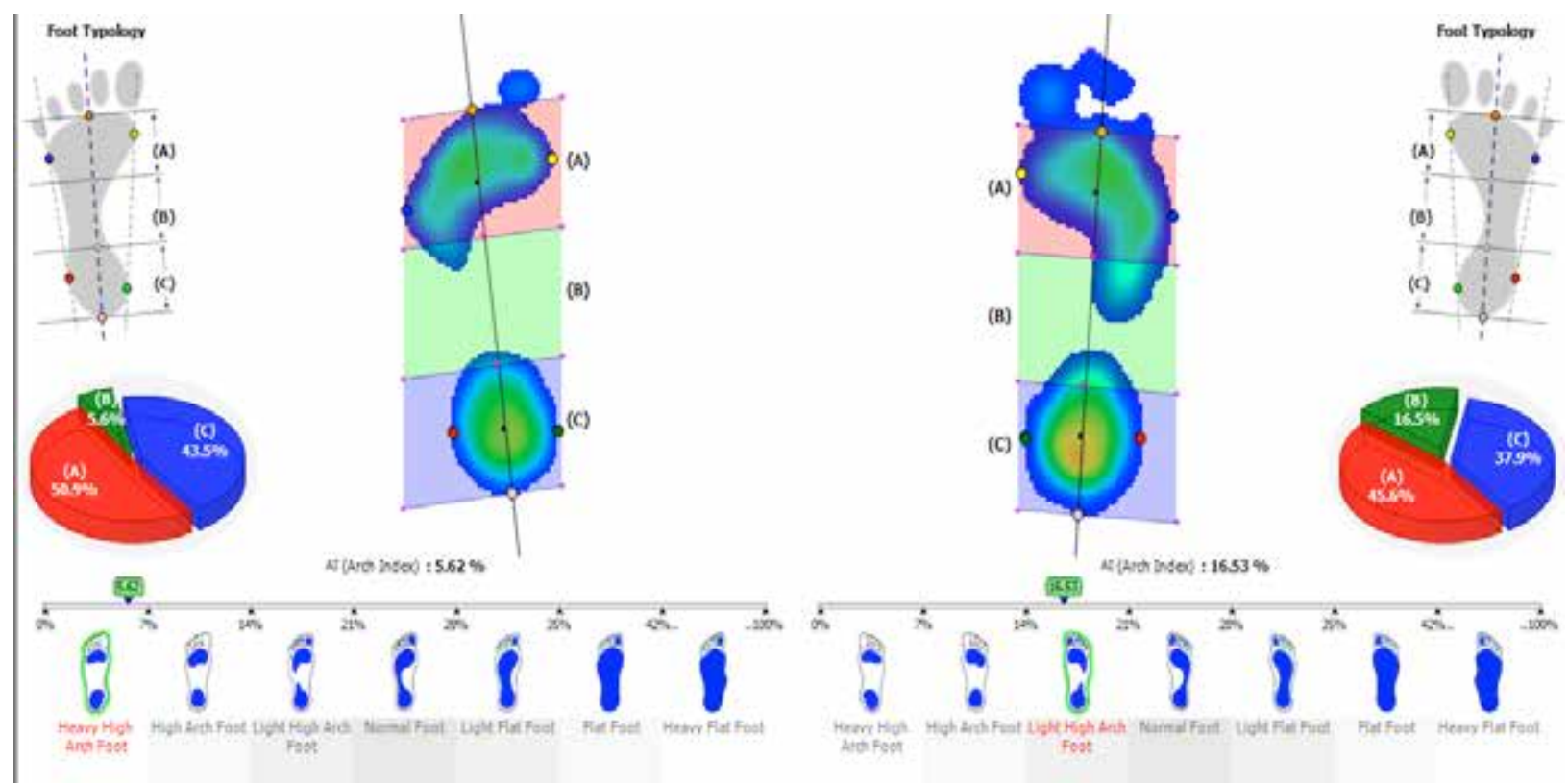

Fig. 2. Sample diagram with the results of the subject's foot pressure distribution of the ground, from the Biomech Studio software

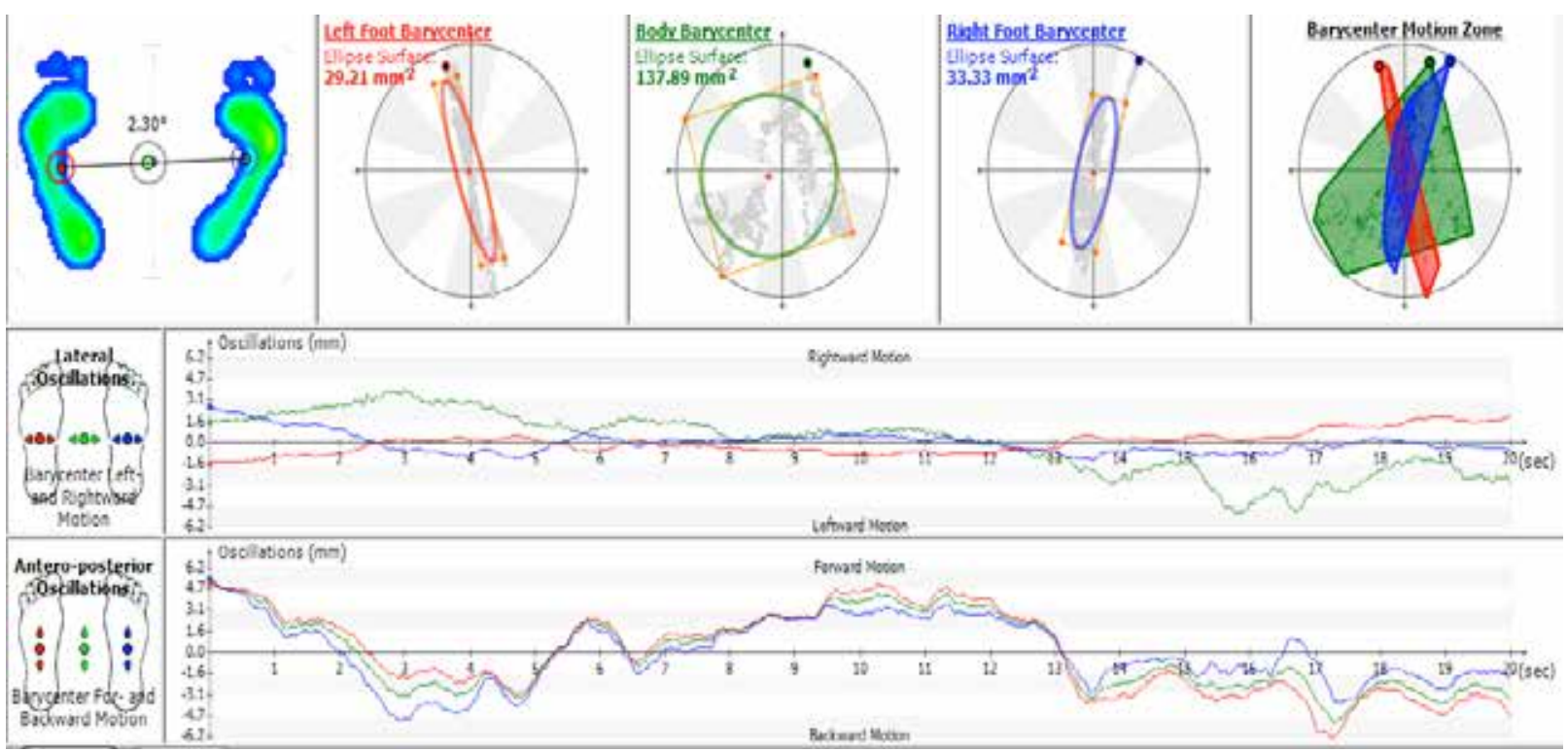

Fig. 3. Sample diagram with the results of the subject's body balance from the Biomech Studio software 


$$
\mathrm{M}=\left(a_{1}+a_{2}+\ldots+a_{n}\right) / n
$$

SD - standard deviation, square root of the variance of the random variable $X$ :

$\sigma(x)=\left(D^{2} x\right)^{-1 / 2}$, one of the most commonly used measures for the spread of random variable values around its expected value $E X$; its empirical equivalent is the standard deviation from a sample, which is a square root of the variance from a sample.

Min. - the minimum value from the sample.

Max. - the maximum value from the sample.

Me - Median (also known as the middle value, the average value or the second quartile) - in statistics, a value of a feature in a ranked (ordered) row, above and below which there is an identical number of observations. A median is a $1 / 2$ quantile, i.e. the second quantile.

$\mathbf{Q}_{1}$ and $\mathbf{Q}_{3}-\mathbf{Q u a r t i l e ~ - ~ a ~ 1 / 4 - q u a n t i l e ~ ( t h e ~ f i r s t ~}$ quartile, the lower quartile), a 1/2-quantile (the second quartile, the median) or a 3/4-quantile (the third quartile, the upper quartile). It is one of the measures of location. The value of $25 \%$ of observations falls below the first quartile, the second quartile divides the group into two equal parts, while the value of $25 \%$ of observations falls above the third quartile (with accuracy of $+/-1$ ). The difference between the third and the first quartile is referred to as inter-quartile range, half of which is the socalled quartile deviation.

The Mann-Whitney-Wilcoxon test (also known as the Mann-Whitney test or sometimes the Wilcoxon Rank Sum Test for two samples, or simply the Wilcoxon test for two samples). Due to the absence of normal distribution of the measurement results in the study population, the non-parametric test function was used.

\section{Results}

New relationships were observed while analysing the number characteristics of the parameters related to the size of the pressure area of selected areas of a foot (Table 3 ). While comparing the average results of measurements at rest and after exercise for the forefoot, it is important to note that they were balanced, where the at-rest value vs the post-exercise value for the left foot amounted to $44.6 \%$ vs $44 \%$, whereas for the right foot -44.65 and $45.7 \%$ respectively. The picture of the midfoot area, being an appropriate reference to correct longitudinal foot arching, was differentiated for both feet in the measurement at rest versus after exercise and amounted to 22.7 vs $23.55 \%$ for the left foot, and 23.6 vs. $24.15 \%$ for the right. For the heel area, the average differences in the values between measurements at rest and after exercise for the left and the right foot amounted to 33.05 and $32.65 \%$, as well as 33 and $31.35 \%$ respectively.

While making a comparative assessment of the values of measurements at rest and after exercise in the population of the female subjects for the midfoot area, which is a measure of the longitudinal foot arching, diverse average values were noted for the left and for the right foot (Table 4). In the case of measurements for the left foot, the post-exercise value decreased from $23.4 \%$ at rest to $23.2 \%$, while for the right foot - the same value increased from 23.7 to $24.3 \%$.

While making a comparative assessment of the values of at-rest and after-exercise measurements in the group of the male subjects, with a particular focus on the midfoot area, increased strain on this area was observed under the post-effort conditions (Table 5). The average value for the left foot increased, on average, from 22.1 at rest to $24 \%$ after exercise, while for the right foot - from 22.5 to $23 \%$ respectively.

The differences in body stabilisation amongst the female and male subjects in the measurements at rest and after exercise were visible in the basic parameters of the posturographic test (Table 6). For the average values of whole body inclinations, for the left and the right foot respectively, it amounted to: $89.6 \mathrm{~mm}^{2}, 37.3 \mathrm{~mm}^{2}$ and $15.6 \mathrm{~mm}^{2}$. The value of standard deviation was significant especially for the post-effort measurement and amounted to over $200 \mathrm{~mm}^{2}$ for $\mathrm{p}$-bars, whereas the difference between the maximum and the minimum values was

Table 3. Number characteristics of the parameters of foot pressure on the ground amongst the study population of women and men $(n=48)$

\begin{tabular}{|c|c|c|c|c|c|c|c|c|c|c|c|c|}
\hline \multirow[b]{2}{*}{$\begin{array}{l}\text { Foot } \\
\text { area [\%] }\end{array}$} & \multicolumn{3}{|c|}{ L foot [at rest] } & \multicolumn{3}{|c|}{$\mathrm{R}$ foot [at rest] } & \multicolumn{3}{|c|}{ L foot [after exercise] } & \multicolumn{3}{|c|}{$R$ foot [after exercise] } \\
\hline & $\begin{array}{l}\text { 뭉 } \\
\frac{0}{0} \\
\text { 훈 }\end{array}$ & 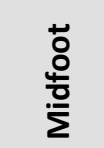 & $\begin{array}{l}\bar{\Phi} \\
\text { I }\end{array}$ & $\begin{array}{l}\text { 艹 } \\
\text { 윰 } \\
\text { 훈 }\end{array}$ & 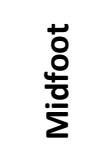 & $\begin{array}{l}\bar{\Phi} \\
\text { I }\end{array}$ & $\begin{array}{l}\text { 艹 } \\
\text { 웅 } \\
\text { 훈 }\end{array}$ & 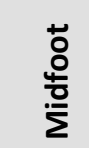 & $\begin{array}{l}\bar{\Phi} \\
\text { I্ }\end{array}$ & 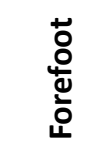 & $\begin{array}{l}\text { to } \\
\stackrel{+}{0} \\
\dot{\Sigma}\end{array}$ & $\begin{array}{l}\bar{\Phi} \\
\frac{\Phi}{x}\end{array}$ \\
\hline$M$ & 44.9 & 21.3 & 33.8 & 44.3 & 21.9 & 33.5 & 44.5 & 22.6 & 32.9 & 45.9 & 22.5 & 31.6 \\
\hline SD & 4.0 & 5.8 & 3.6 & 7.2 & 5.8 & 4.0 & 3.6 & 5.6 & 3.7 & 3.2 & 5.2 & 3.7 \\
\hline Min. & 38.3 & 5.9 & 26.7 & 4.7 & 4.9 & 25.2 & 37.1 & 5.6 & 26.1 & 40.2 & 4.3 & 21.8 \\
\hline Max. & 55.2 & 29.1 & 45.7 & 54.8 & 31.8 & 44.8 & 54.3 & 31.5 & 43.5 & 57.5 & 28.6 & 43.0 \\
\hline Me & 44.67 & 22.7 & 33.1 & 44.7 & 23.6 & 33.0 & 44.0 & 23.6 & 32.7 & 45.7 & 24.2 & 31.4 \\
\hline $\mathrm{Q}_{1}$ & 42.4 & 20.6 & 31.8 & 42.8 & 18.6 & 31.2 & 42.7 & 21.3 & 31.3 & 43.8 & 20.8 & 29.7 \\
\hline$Q_{3}$ & 46.4 & 25.3 & 36.1 & 46.6 & 25.4 & 35.2 & 45.4 & 25.9 & 34.0 & 47.7 & 26.0 & 33.1 \\
\hline
\end{tabular}

Legend: $\mathbf{L}$ - left, $\mathbf{R}$ - right, $\mathbf{M}$ - the arithmetic mean of a sample, SD - standard deviation, Min. - minimum value of a sample, Max. - maximum value of a sample, $\mathbf{M e}$ - the middle average of a sample, $\mathbf{Q}_{1}, \mathbf{Q}_{3}$ - extreme quartiles. 
Table 4. Number characteristics of the parameters of foot pressure on the ground amongst the study population of women $(n=37)$

\begin{tabular}{|c|c|c|c|c|c|c|c|c|c|c|c|c|}
\hline \multirow[b]{2}{*}{$\begin{array}{l}\text { Foot area } \\
\text { [\%] }\end{array}$} & \multicolumn{3}{|c|}{ L foot [at rest] } & \multicolumn{3}{|c|}{$\mathrm{R}$ foot [at rest] } & \multicolumn{3}{|c|}{ L foot [after exercise] } & \multicolumn{3}{|c|}{ R foot [after exercise] } \\
\hline & $\begin{array}{l}\text { 뭉 } \\
\text { 윤 } \\
\text { 인 }\end{array}$ & 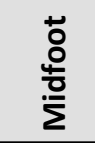 & $\begin{array}{l}\bar{\Phi} \\
\text { Ф் }\end{array}$ & $\begin{array}{l}\text { 음 } \\
\text { 윤 } \\
\text { 혼 }\end{array}$ & $\begin{array}{l}\text { 음 } \\
\stackrel{0}{0} \\
\stackrel{0}{0}\end{array}$ & $\begin{array}{l}\bar{\Phi} \\
\stackrel{\Phi}{I}\end{array}$ & $\begin{array}{l}\text { 음 } \\
\text { 유 } \\
\text { 인 }\end{array}$ & 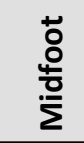 & $\begin{array}{l}\bar{\Phi} \\
\text { 京 }\end{array}$ & $\begin{array}{l}\text { ㅇ } \\
\text { 유 } \\
\text { 힌 }\end{array}$ & $\begin{array}{l}\stackrel{0}{\circ} \\
\stackrel{0}{0} \\
\frac{0}{2} \\
\Sigma\end{array}$ & $\begin{array}{l}\bar{\Phi} \\
\text { I্ }\end{array}$ \\
\hline M & 44.3 & 21.7 & 34.0 & 43.4 & 22.5 & 33.4 & 44.3 & 22.7 & 33.0 & 45.5 & 22.9 & 31.7 \\
\hline SD & 3.8 & 5.7 & 3.7 & 7.6 & 5.8 & 3.8 & 3.8 & 5.8 & 3.9 & 2.7 & 4.5 & 3.5 \\
\hline Min. & 38.3 & 5.9 & 26.7 & 4.7 & 4.9 & 25.2 & 37.1 & 5.6 & 26.1 & 40.2 & 4.5 & 25.9 \\
\hline Max. & 55.2 & 29.1 & 45.7 & 54.8 & 31.8 & 44.8 & 54.3 & 31.5 & 43.5 & 57.5 & 28.6 & 43.0 \\
\hline Me & 43.7 & 23.4 & 33.0 & 44.4 & 23.7 & 33.2 & 44.4 & 23.2 & 32.4 & 45.4 & 24.3 & 31.3 \\
\hline$Q_{1}$ & 41.7 & 20.8 & 31.9 & 42.6 & 20.2 & 31.1 & 42.2 & 21.4 & 31.2 & 43.9 & 20.9 & 29.7 \\
\hline $\mathbf{Q}_{3}$ & 46.8 & 24.6 & 36.8 & 46.6 & 25.1 & 35.3 & 45.9 & 24.6 & 34.0 & 47.8 & 25.7 & 33.2 \\
\hline
\end{tabular}

Legend: $\mathbf{L}$ - left, $\mathbf{R}$ - right $\mathbf{M}$ - the arithmetic mean of a sample, SD - standard deviation, Min. - minimum value of a sample, Max. - maximum value of a sample, $\mathbf{M e}$ - the middle average of a sample, $\mathbf{Q}_{\mathbf{1}}, \mathbf{Q}_{\mathbf{3}}$ - extreme quartiles.

Table 5. Number characteristics of the parameters of foot pressure on the ground amongst the study population of men $(n=11)$

\begin{tabular}{|c|c|c|c|c|c|c|c|c|c|c|c|c|}
\hline \multirow[b]{2}{*}{$\begin{array}{l}\text { Foot area } \\
\text { [\%] }\end{array}$} & \multicolumn{3}{|c|}{ L foot [at rest] } & \multicolumn{3}{|c|}{$\mathrm{R}$ foot [at rest] } & \multicolumn{3}{|c|}{ L foot [after exercise] } & \multicolumn{3}{|c|}{$\mathrm{R}$ foot [after exercise] } \\
\hline & $\begin{array}{l}\text { 음 } \\
\text { 는 } \\
\text { 이 }\end{array}$ & 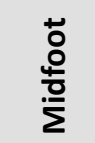 & $\begin{array}{l}\bar{\Phi} \\
\text { I }\end{array}$ & 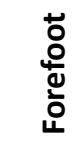 & $\begin{array}{l}\text { ㅇ } \\
\text { 운 } \\
\frac{0}{\Sigma}\end{array}$ & $\begin{array}{l}\bar{\Phi} \\
\text { İ }\end{array}$ & $\begin{array}{l}\text { 응 } \\
\text { 윰 } \\
\text { 이 }\end{array}$ & 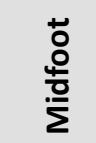 & $\begin{array}{l}\bar{\Phi} \\
\stackrel{\Phi}{I}\end{array}$ & $\begin{array}{l}\text { 응 } \\
\text { 뉸 } \\
\text { 유 }\end{array}$ & 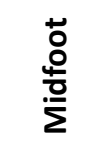 & $\begin{array}{l}\bar{\Phi} \\
\text { İ }\end{array}$ \\
\hline$M$ & 46.9 & 19.8 & 33.3 & 47.4 & 19.8 & 34.1 & 45.0 & 22.4 & 32.6 & 47.4 & 21.3 & 31.4 \\
\hline SD & 4.0 & 6.2 & 3.0 & 4.2 & 5.8 & 4.8 & 3.1 & 5.1 & 2.7 & 4.4 & 7.2 & 4.4 \\
\hline Min. & 42.8 & 10.3 & 28.5 & 42.2 & 11.0 & 28.4 & 42.3 & 11.2 & 27.0 & 41.9 & 4.3 & 21.8 \\
\hline Max. & 55.2 & 27.3 & 38.6 & 54.8 & 27.0 & 44.8 & 51.9 & 28.8 & 36.9 & 57.5 & 28.6 & 38.2 \\
\hline Me & 44.9 & 22.1 & 33.8 & 45.5 & 22.5 & 31.7 & 43.8 & 24.0 & 32.7 & 47.2 & 23.0 & 32.0 \\
\hline$Q_{1}$ & 44.5 & 15.6 & 31.4 & 44.6 & 14.8 & 31.3 & 43.1 & 20.4 & 32.4 & 44.1 & 18.2 & 30.0 \\
\hline$Q_{3}$ & 48.8 & 24.1 & 34.8 & 50.2 & 24.2 & 35.4 & 45.4 & 24.6 & 33.8 & 49.1 & 25.9 & 32.9 \\
\hline
\end{tabular}

Legend: $\mathbf{L}$ - left, $\mathbf{R}$ - right, $\mathbf{M}$ - the arithmetic mean of a sample, SD - standard deviation, Min. - minimum value of a sample, Max. - maximum value of a sample, $\mathbf{M e}$ - the middle average of a sample, $\mathbf{Q}_{\mathbf{1}}, \mathbf{Q}_{\mathbf{3}}$ - extreme quartiles.

Table 6. Number characteristics of the stabilographic parameters for the female and male subjects $(n=48)$

\begin{tabular}{|c|c|c|c|c|c|c|c|c|c|c|c|c|}
\hline \multirow[b]{2}{*}{ 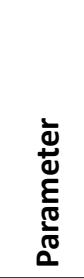 } & \multicolumn{3}{|c|}{ Measurement at rest } & \multicolumn{9}{|c|}{ Post-exercise measurement } \\
\hline & 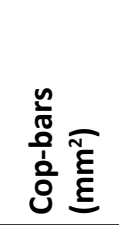 & 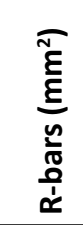 & 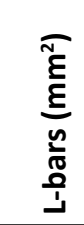 & $\frac{\frac{\pi}{n}}{\frac{0}{0}}$ & 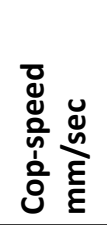 & 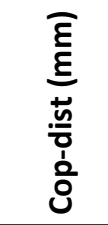 & 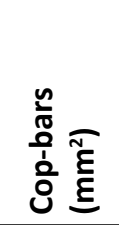 & 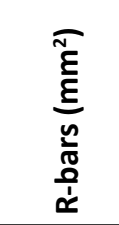 & 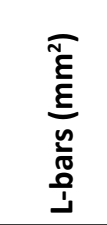 & $\frac{4}{\frac{5}{0}}$ & 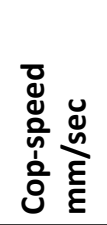 & 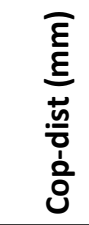 \\
\hline M & 48.8 & 21.3 & 16.1 & 3.6 & 5.4 & 107.1 & 177.3 & 113.1 & 84.3 & 1.6 & 6.9 & 136.4 \\
\hline SD & 35.2 & 21.6 & 14.8 & 2.6 & 0.9 & 16.9 & 141.5 & 239.7 & 164.0 & 1.8 & 1.7 & 35.2 \\
\hline Min. & 9.9 & 1.9 & 1.0 & 0.8 & 4.0 & 81.0 & 11.5 & 3.4 & 2.4 & 0.3 & 4.3 & 85.6 \\
\hline Max. & 176.6 & 98.2 & 70.8 & 10.6 & 8.0 & 159.9 & 611.9 & 1486.8 & 951.8 & 10.3 & 13.8 & 276.2 \\
\hline Me & 38.3 & 11.9 & 12.3 & 2.9 & 5.3 & 105.0 & 127.9 & 49.2 & 27.9 & 1.0 & 6.5 & 127.2 \\
\hline $\mathrm{Q}_{1}$ & 19.4 & 6.1 & 5.2 & 1.6 & 4.9 & 98.0 & 70.7 & 14,4 & 15.9 & 0,6 & 5.9 & 113.3 \\
\hline$Q_{3}$ & 68.6 & 29.4 & 20.5 & 4.8 & 5.7 & 111.5 & 266.4 & 104.9 & 77.0 & 1.7 & 7.7 & 154.3 \\
\hline
\end{tabular}

Legend: Cop-bars - surface of deflections of the body's centre of gravity, R-bars - right foot deflection area, L-bars - left foot deflection area, Cop-Isf - ratio of the distance between extreme deflections to the deflection surface, Copspeed - deflections speed of body's centre of gravity, Cop-dist - distance between extreme deflections of the body's centre of gravity, $\mathbf{M}$ - the arithmetic mean of a sample, SD - standard deviation, Min. - minimum value of a sample, Max. - maximum value of a sample, $\mathbf{M e}$ - the middle average of a sample, $\mathbf{Q}_{1}, \mathbf{Q}_{3}$ - extreme quartiles. 
nearly $1.500 \mathrm{~mm}^{2}$.

Similarly, differences were searched for in the population of the female subjects and, again, significant increase in the measurement values was found after exercise (Table 7). The difference for the whole body amounted to $92.5 \mathrm{~mm}^{2}$, for the right foot $-33.9 \mathrm{~mm}^{2}$, and for the left foot $-13.2 \mathrm{~mm}^{2}$. A significant spread of the measurement values around the average result appeared again in the population of the female subjects, due to the fact that such significant disorders of the balance function were noted in the individuals from this population.

Identical result summaries were analysed in the study population of men (Table 8). The average differences for the basic assessment parameters of the inclination area were as follows: for the whole body $-81.9 \mathrm{~mm}^{2}$, for the right foot $-42.8 \mathrm{~mm}^{2}$, and for the left foot $-19.4 \mathrm{~mm}^{2}$. In the male population, the dispersion of measurement results was not as significant as in the population of female

Table 7. Number characteristics of the stabilographic parameters for the female subjects $(n=37)$

\begin{tabular}{|c|c|c|c|c|c|c|c|c|c|c|c|c|}
\hline \multirow[b]{2}{*}{ 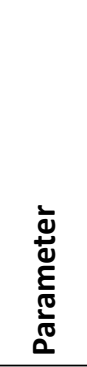 } & \multicolumn{6}{|c|}{ Measurement at rest } & \multicolumn{6}{|c|}{ Post-exercise measurement } \\
\hline & 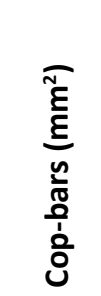 & 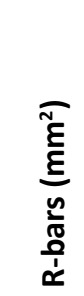 & 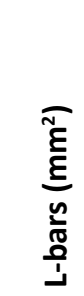 & $\frac{\frac{4}{n}}{\frac{1}{0}}$ & 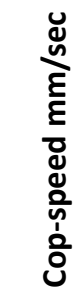 & 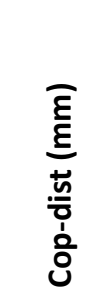 & 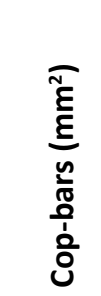 & 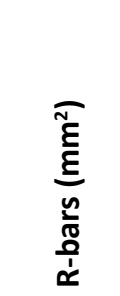 & 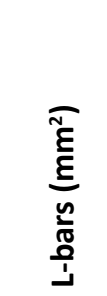 & $\frac{\frac{4}{1}}{\frac{1}{0}}$ & 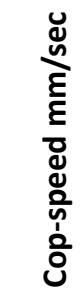 & 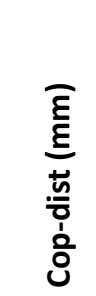 \\
\hline M & 51.5 & 22.1 & 17.8 & 3.6 & 5.3 & 105.7 & 179.5 & 124.6 & 90.0 & 1.7 & 6.8 & 134.2 \\
\hline SD & 38.4 & 22.8 & 15.3 & 2.8 & 0.9 & 16.8 & 152.2 & 270.4 & 182.8 & 2.0 & 1.8 & 37.6 \\
\hline Min. & 9.9 & 1.9 & 1.7 & 0.8 & 4.0 & 81.0 & 11.5 & 3.4 & 2.4 & 0.3 & 4.3 & 85.6 \\
\hline Max. & 176.6 & 98.2 & 70.8 & 10.6 & 8.0 & 159.9 & 611.9 & 1486.8 & 951.8 & 10.3 & 13.8 & 276.2 \\
\hline Me & 45.4 & 13.1 & 15.2 & 1.9 & 5.1 & 102.3 & 137.9 & 47.0 & 28.4 & 1.0 & 6.3 & 124.7 \\
\hline$Q_{1}$ & 19.4 & 6.1 & 7.7 & 1.6 & 4.9 & 97.0 & 65.3 & 14.9 & 16.2 & 0,6 & 5.7 & 111.6 \\
\hline$Q_{3}$ & 71.0 & 32.7 & 22.4 & 4.7 & 5.6 & 109.3 & 263.8 & 104.3 & 77.1 & 1.8 & 7.7 & 153.8 \\
\hline
\end{tabular}

Legend: Cop-bars - surface of deflections of the body's centre of gravity, R-bars - right foot deflection area, L-bars - left foot deflection area, Cop-Isf - ratio of the distance between extreme deflections to the deflection surface, Copspeed - deflections speed of body's centre of gravity, Cop-dist - distance between extreme deflections of the body's centre of gravity, $\mathbf{M}$ - the arithmetic mean of a sample, $\mathbf{S D}$ - standard deviation, Min. - minimum value of a sample, Max. - maximum value of a sample, $\mathbf{M e}$ - the middle average of a sample, $\mathbf{Q}_{1}, \mathbf{Q}_{\mathbf{3}}$ - extreme quartiles.

Table 8. Number characteristics of the stabilographic parameters for the male subjects $(n=11)$

\begin{tabular}{|c|c|c|c|c|c|c|c|c|c|c|c|c|}
\hline \multirow[b]{2}{*}{ 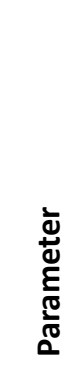 } & \multicolumn{6}{|c|}{ Measurement at rest } & \multicolumn{6}{|c|}{ Post-exercise measurement } \\
\hline & 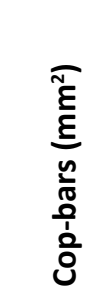 & 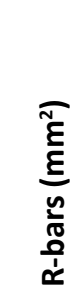 & 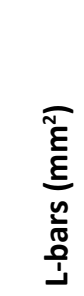 & $\frac{\frac{\hbar}{\frac{1}{1}}}{\frac{0}{0}}$ & 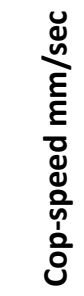 & 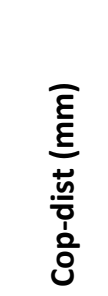 & 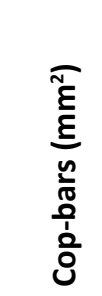 & 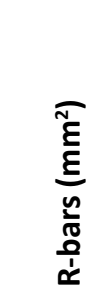 & 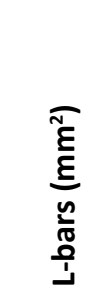 & $\frac{\overleftarrow{n}}{\frac{\pi}{0}}$ & 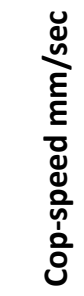 & 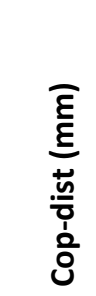 \\
\hline M & 39.8 & 18.3 & 10.2 & 3.5 & 5.6 & 111.8 & 170.1 & 74.5 & 65.4 & 1.2 & 7.2 & 143.6 \\
\hline SD & 20.2 & 17.5 & 11.7 & 1.7 & 0.9 & 17.1 & 103.1 & 68.9 & 74.8 & 0.7 & 1.3 & 25.5 \\
\hline Min. & 17.1 & 2.4 & 1.0 & 1.4 & 4.7 & 94.4 & 41.0 & 11.3 & 13.4 & 0.5 & 5.2 & 104.1 \\
\hline Max. & 75.4 & 57.6 & 43.1 & 6.9 & 7.8 & 155.1 & 329.8 & 198.9 & 253.1 & 2.5 & 9.7 & 193.2 \\
\hline Me & 36.0 & 11.2 & 7.4 & 3.1 & 5.4 & 107.5 & 117.9 & 54.0 & 26.8 & 1.0 & 6.9 & 138.6 \\
\hline $\mathbf{Q}_{1}$ & 23.4 & 7.9 & 3.7 & 2.2 & 5.1 & 101.7 & 88.7 & 16.0 & 19.9 & 0.7 & 6.4 & 127.9 \\
\hline$Q_{3}$ & 52.6 & 22.1 & 10.9 & 4.5 & 5.9 & 1166 & 259.2 & 107.1 & 70.9 & 1.6 & 8.1 & 162.2 \\
\hline
\end{tabular}

Legend: Cop-bars - surface of deflections of the body's centre of gravity, R-bars - right foot deflection area, L-bars - left foot deflection area, Cop-Isf - ratio of the distance between extreme deflections to the deflection surface, Copspeed - deflections speed of body's centre of gravity, Cop-dist - distance between extreme deflections of the body's centre of gravity, $\mathbf{M}$ - the arithmetic mean of a sample, $\mathbf{S D}$ - standard deviation, Min. - minimum value of a sample, Max. - maximum value of a sample, $\mathbf{M e}$ - the middle average of a sample, $\mathbf{Q}_{\mathbf{1}}, \mathbf{Q}_{\mathbf{3}}$ - extreme quartiles. 
subjects, which was manifested in the value of standard deviation. The highest value of this spread was noted for the whole-body parameter (cop-bars) and amounted to $103.1 \mathrm{~mm}^{2}$.

While making a comparative assessment of the average measurements values for the body balance ability, lower body stabilisation was found for each of the parameters of the stabilographic test for all the subjects, as well as for the population of females and males (Tables $6,7,8)$. Clarification should be given for the inversely proportional value of the cop-lsf parameter, which - as a measure of relationship between two parameters assumes nominally higher values for the measurement at rest. The value of the median, assumed to be the measure for non-normal distributions (Gaussian distribution), indicates differences from 17 to $79 \%$. The highest value was noted for p-bars in the male population, i.e. $11.2 \mathrm{~mm}^{2}$ in the measurement at rest and $54 \mathrm{~mm}^{2}$ in the measurement after exercise. The highest percentage value was observed for the cop-dist parameters for the entire study population, with the at-rest value amounting to $105 \mathrm{~mm}$, and the posteffort value - to $127.2 \mathrm{~mm}$.

\section{Discussion}

The review included literature from the following databases: PEDro, PubMed, Medline, Embase and Scopus. The authors found no study that would use the same methodology. The discussion focuses on articles which are as close as possible to the authors' original project presented above. The authors' own study revealed that the participants in the tests, in terms of foot pressure distribution on the ground both before and after an effort stimulus, showed statistically significant differences in 6 out of the 10 parameters under analysis (Table 9).

Table 9. Significance of the differences between the measurement at rest and after exercise $[n=48]$

\begin{tabular}{llll}
\hline Pair of variables & $\mathbf{T}$ & $\mathbf{Z}$ & $\mathbf{p}$ \\
\hline Front [\%] & 213.5000 & 3.841076 & 0.000123 \\
\hline Back [\%] & 225.5000 & 3.717998 & 0.000201 \\
\hline $\begin{array}{l}\text { Longitudinal arch } \\
\text { LF [\%] }\end{array}$ & 334.0000 & 2.605162 & 0.009183 \\
\hline $\begin{array}{l}\text { Longitudinal arch } \\
\text { RF [\%] }\end{array}$ & 483.5000 & 1.071809 & 0.283807 \\
\hline Forefoot LF [\%] & 531.5000 & 0.343920 & 0.730907 \\
\hline Midfoot LF [\%] & 335.0000 & 2.594906 & 0.009462 \\
\hline Heel LF [\%] & 321.0000 & 2.571465 & 0.010127 \\
\hline Forefoot RF [\%] & 495.0000 & 0.953859 & 0.340156 \\
\hline Midfoot RF [\%] & 469.0000 & 1.005305 & 0.314751 \\
\hline Heel RF [\%] & 228.5000 & 3.550314 & 0.000385 \\
\hline
\end{tabular}

Wilcoxon Matched Pairs Test $p<, 05000$

Statistically significant differences were also achieved in the results of the analysed characteristics concerning the level of body balance. It should be noted that the pre-set effort stimuli had a significant effect on the manifestation of body balance in the subjects. This concerned all the parameters (Table 10).

Table 10. Significance of the differences in maintaining balance between the measurement at rest and after exercise $[n=48]$

\begin{tabular}{llll}
\hline Pair of variables & $\mathbf{T}$ & $\mathbf{Z}$ & $\mathbf{p}$ \\
\hline Cop-bars [mm2] & 27.0000 & 5.753922 & 0.000000 \\
\hline P-bars [mm2] & 139.0000 & 4.605189 & 0.000004 \\
L-bars [mm2] & 84.0000 & 5.169299 & 0.000000 \\
Cop-dist [mm] & 78.5000 & 5.225710 & 0.000000 \\
$\begin{array}{l}\text { Cop-speed [mm/ } \\
\text { sec] }\end{array}$ & 70.0000 & 5.227586 & 0.000000 \\
Cop-lsf: & 101.5000 & 4.989809 & 0.000001 \\
\hline
\end{tabular}

Wilcoxon Matched Pairs Test $p<, 05000$

Similar analyses were undertaken by Mucha et al. [17]. The objective of their paper was to assess the foot arching degree and the distribution of foot pressure on the ground amongst female students of the Podhale State Higher Vocational School in Nowy Targ (PPWSZ). The study was conducted in March 2015 and encompassed 32 female students of the PPWSZ, aged 20 to 24 years. The average age was 21.43 years. The comparative assessment of the subjects' somatic features was performed using the results of the comparative group. Somatic features such as body height, body weight, foot length and width were evaluated, and foot arching was assessed, determining the Clarke's angle and the Wejsflog index (using a 2D podoscanner), the sole area of the feet and the distribution of foot pressure on a ground reaction forces platform (FreeMed).

A different approach to the issue of external factors affecting foot pressure on the ground was applied by Tae-Ho et al. [18]. The aim of this study was to examine the effect of a pelvis-concentrated exercise programme and walking on the changes in body shape and foot base pressure. Thirty adults from K University in Busan, Republic of Korea, were randomly divided into the Swiss-ball exercise group and McKenzie exercise group, and they conducted exercise for 40 minutes 3 times a week for 6 weeks. Global postural system results and foot base pressure significantly decreased in both groups. A comparison of foot base pressure after the intervention between the two groups revealed that the Swiss-ball exercise group exhibited a greater reduction than the McKenzie exercise group. The results of this study indicated that the Swiss-ball exercise may improve posture and foot base pressure in male adults.

The analysis of how a specific type physical effort affects the level of selected functional parameters of the human body was undertaken by Sterkowicz et al. [19]. Years of training in competitive sports leads to human body adaptation to a specific type of exercise. In judo bouts, maintaining hand grip on an opponent's clothes 
and postural balance is essential for the effective technical and tactical actions. This study compares changes after maximal anaerobic exercise among judo athletes and untrained subjects regarding 1) maximum isometric handgrip strength (HGSmax) and accuracy at the perceived $50 \%$ maximum handgrip force (1/2HGSmax) and 2) the balance of 13 judo athletes at national (n $=8)$ and international $(\mathrm{n}=5)$ competitive levels and 19 untrained university students. The groups did not differ in age, body height, or weight. Body mass index (BMI) and body composition (JAWON) were evaluated. The Wingate Anaerobic Test (WAnT, Monark 875E) measured recommended anaerobic capacity indices. Hand grip strength (Takei dynamometer) and balance (biplate balance platform) were measured before warmup (T1), before the WAnT test (T2), and after (T3). Parametric or non-parametric tests were performed after verifying the variable distribution assumption. Judoists had higher BMI and fat-free mass index (FFMI) than the students. The athletes also showed higher relative total work and relative peak power and lower levels of lactic acid. The difference in judoists between HGSmax at T1 and HGSmax at T3 was statistically significant. Before warm-up (T1), athletes showed higher strength (more divergent from the calculated $1 / 2$ HGSmax value) compared to students. Substantial fatigue after the WAnT test significantly deteriorated the body stability indices, which were significantly better in judo athletes at all time points. The findings suggest specific body adaptations in judoists, especially for body composition, anaerobic energy system efficiency, and postural balance. These characteristics could be trained for specifically by judo athletes to meet the time-motion and anaerobic demands of contemporary bouts.

Striking differences in the level of body balance under extreme physical effort were observed by Kruczkowski and Jaszczur-Nowicki [20]. Based on the tests of student athletes representing the highest level of sports preparation, they indicated that extreme physical effort in those individuals was a specific kind of a "warm-up" for the balance function of the body. After physical effort typical of their sport, the athletes achieved higher levels of body stabilisation than under at-rest conditions.

The issue of body balance amongst students was also undertaken by Hyouk Hyong et al. [21]. This study aimed to compare dynamic balance ability according to foot shape, defined as normal, pronated, or supinated on the basis of the height of the medial arch. In this study, 14 subjects for the pronated foot group, 14 for the supinated foot group, and 14 for the normal foot group were selected from among 162 healthy university students by using the navicular drop test proposed by Brody. To measure dynamic balance ability, a star excursion balance test (SEBT) was conducted for each group, in which a crossshaped line and lines at $45^{\circ}$ in eight directions were drawn on the floor. In this study, only three directions were used, namely anterior, posterolateral, and posteromedial. The mean of the SEBT was calculated by measuring three times for each group, and the values were standardized using the following equation: measured value/leg length $\times$ 100. No significant differences in dynamic balance ability were found between the normal, pronated, and supinated foot groups. No significant differences in dynamic balance ability according to the foot shape were found among the healthy university students with normal, pronated, and supinated feet.

Interesting test results were obtained by Zanevskyy and Nowak [22]. Ten 19-21 years old university students were involved in the research. The test consisted of five measurements - each of them in another feet situation with ten minutes relax before every measurement. Measurements were done using two twin platforms kinesismeter CQStab2P. A length of the horizontal projection of centre of pressure for 30 seconds was measured as a test result. They concluded that in the balance control of the orthostatic body pose in the physical education of students a feet situation should be taken into consideration, because a significant difference between lengths of the centre of pressure during the control on the balance platform relatively a body pose $(p<.046)$. Balance testing on the platform could be conducted on the appropriable, good, and excellent levels of reliability using intra-class correlation coefficient $(I C C=0.791-0.975)$.

The issue of how a specific stimulus in the form of body vibration affects the level of body balance was undertaken by Duygu [23]. The purpose of the present study was to examine the effect of acute Whole Body Vibration (WBV) on static and dynamic balance in physical education students. A total of 30 healthy physical education students participated in this study. The participants were divided into two groups as the Control Group $(n=15)$ and the Whole Body Vibration group $(\mathrm{n}=15)$. The control group did not undergo any training sessions; and the WBV group did acute WBV. The first measurements of height, weight, flamingo balance test for static balance, and the $\mathrm{Y}$ balance test for dynamic balance were made for both groups before applying the WBV program. The final measurements were made right after the WBV application. Results are presented as mean \pm standard deviation. The values that were obtained from the pre-test and post-test were analysed with the paired sample t-test after their normality was checked with the Shapire-Wilk Test. The comparisons between the groups were analysed by using an independent sample t-test at a significance level of $p<0.05$. The flamingo balance test was applied to determine the static balance values. According to the flamingo balance test, there was a significant difference between the right leg pre-test and post-test values of the WBV group $(\mathrm{p}<0.05)$. A significant difference was detected between the left leg pre-test and post-test values of the WBV group $(\mathrm{p}<0.05)$. The Y balance test was applied to determine the dynamic balance results. There was a significant difference between the right leg pre-test and post-test values of the WBV group $(p<0.05)$. There was a significant difference between the left leg pre-test and post-test values of the WBV group. It was determined that the acute WBV has a positive effect on static and dynamic balance. 


\section{Conclusions}

Significant differences reflecting the impact of the effort stimuli were expected to be achieved during the mathematical analysis of the results of podobarographic tests that allow for the assessment of the physiological parameters of foot arching and the functional efficiency of the body balance system under different measurement conditions. The authors' assumption was mathematically and statistically confirmed by significant differences for most of the parameters arising out of the possibilities offered by the research method applied. Comparative assessment unquestionably revealed a negative change in foot arching, as well as lower body posture stability in the female and male subjects, resulting from the physical exercise applied.

\section{Information on financial support}

The authors declare no financial support regarding this paper.

\section{Conflict of Interest}

The authors declare that there is no conflict of interest regarding this research.

\section{Reference}

1. Jaszczur-Nowicki J, Kruczkowski D, Bukowska JM, Analysis of the distribution of foot force on the ground before and after a kinaesthetic stimulation. Journal of Kinesiology and Exercise Sciences, 2019; 86 (29): 19-27. https://doi.org/10.5604/01.3001.0014.1273

2. Urych I: Motoryczność człowieka [The motoric nature of man]. Roczniki Naukowe WSWFiT w Bialystoku, 2014;10(10):79-82. (in Polish)

3. Malina RM. Physical activity and health of youth. Ovidius University Annals, Series Physical Education \& Sport/ Science, Movement \& Health, 2010;10(2): 271-277.

4. Kruczkowski D, Jaszczur-Nowicki J. Zdolność zachowania równowagi ciała $w$ różnych aspektach biologicznej $i$ sportowej determinacji. [The ability to maintain the balance of the body in various aspects of biological and sporting determination]. Olsztyn: Publishing house of the University of Warmia and Mazury; 2015. (in Polish)

5. Leszczak J, Drzał-Grabiec J, Rykała J, PodgórskaBednarz J, Rachwał M. Charakterystyka wybranych parametrów antropometrycznych kończyn dolnych w warunkach odciążenia i obciążenia masą własną u dzieci w wieku szkolnym [Characteristics of chosen lower limb anthropometric parameters in non-weight bearing and in weight-bearing conditions in school children]. Medical Review, 2014; 1: 55-61. (in Polish)

6. Grabiec-Drzał J: Wpływ masy ciała na wysklepienie łuku podłużnego stóp [Influence of body mass on longitudinal arch of the feet]. Probl Hig Epidemiol, 2012; 93(2):315-318. (in Polish)

7. Puszczałkowska-Lizis E. Związki kąta Clarke'a z cechami przedniej i tylnej strefy podparcia oraz częstość występowania deformacji stóp u kobiet $\mathrm{w}$ wieku geriatrycznym [The relationships of Clarke's angle with structural features of the forefoot and hindfoot and the prevalence of foot deformity in geriatric patients]. Gerontologia Polska, 2011; 19(1): 33-39. (in Polish)

8. Mickle KJ, Steele JR, Munro BJ. The feet of overweight and obese young children: are they flat or fat? Obesity, 2006; 14(11): 1949-1953. https://doi.org/10.1038/oby.2006.227

9. ElO,AkcaliO,KosayC,KanerB,ArslanY,SagolE, etal.Flexible flatfoot and related factors in primary school children: a report of a screening study. Rheumatol Int, 2006; 26: 1050-1053. https://doi.org/10.1007/s00296-006-0128-1

10.Pfeiffer M, Kotz R, Ledl T, Hauser G, Sluga M. Prevalence of flat foot in preschool - aged children. Pediatrics. 2006; 118: 634-639. https://doi.org/10.1542/peds.2005-2126
11.Michnik R, Jurkoić J, Wodarski P, Gzik M, JochymczykWożniak K. Bieniek A. The influence of frequency of visual disorders on stabilographic parameters. Acta of Bioengineering and Biomechanics, 2016; 18(1): 25-33. DOI: 10.5277/ABB-00201-2014-04

12.Libardoni TC, de Silveira CB, Sinhorim LMB, de Oliviera AS, dos Santos MJ, Santos GM. Reference values and equations reference of balance for children of 8 to 12 years. Gait \& Posture, 2018; 60: 122-127. https://doi.org/10.1016/j.gaitpost.2017.11.004

13.Kidoń Z, Fiołka J. Analiza harmoniczna zespolonego sygnału stabilograficznego [Harmonic analysis of a complex-valued stabilographic signal]. Przeglad Elektrotechniczny, 2017; 93(4): 185-188. https://doi.org/10.15199/48.2017.04.43 (in Polish)

14.Bukowska J. M, Krawczyński M, Jaszczur-Nowicki J. Human gait structure on stable and unstable surfaces. Journal of Kinesiology and Exercise Sciences, 2019; 87 (29). (in press) https://doi.org/10.5604/01.3001.0014.1273

15.Inoue K, Uematsu M, Maruoka H, Hara K, Kanemura N, Masuda T, Morita S. Influence of Lower Limb Muscle Fatigue on Balance Function. J. Phys. Ther. Sci., 2013; 25: 331- 335. https://doi.org/10.1589/jpts.25.331

16.Mańko G, Kruczkowski D, Niźnikowski T, Perliński $\mathrm{J}$, Chantsoulis $\mathrm{M}$, et al. The effect of programed physical activity measured with levels of body balance maintenance. Med Sci Monit, 2014; 20: 1841-1849. https://doi.org/10.12659/MSM.889521

17.Mucha D, Ambroży T, Mucha D, Koteja P. Foot arch and distribution of ground pressure of feet of students of the Podhale State Higher Vocational School in Nowy Targ (PPWSZ). Security, Economy \& Law, 2015; 4(9): 117-133.

18.Tae-Ho Kim, Chae-Woo Lee, Seong-Gil Kim, ByungWook An. The effect of a pelvis-concentrated exercise program on male college students' body alignment and foot base pressure. J. Phys. Ther. Sci., 2015; 27: 1165-1167. https://doi.org/10.1589/jpts.27.1165

19.Sterkowicz S, Jaworski J, Lech G, Pałka T, SterkowiczPrzybycień K, Bujas $P$, et al. Effect of Acute Effort on Isometric Strength and Body Balance: Trained vs. Untrained Paradigm, PLoS One, 2016; 11(5). https://doi.org/10.1371/journal.pone.0155985

20. Kruczkowski D, Jaszczur-Nowicki J, Tomiak T. Evaluating the body balance maintaining ability in the endurance effort context. In: Coordination motor abilities in scientific research (Jerzy Sadowski and Tomasz Niźnikowski ed.). Biała Podlaska: Józef Piłsudski Academy of Physical Education in Warsaw. 
Faculty of Physical Education; 2008. P.294-299.

21.Hyouk Hyong I, Ho Kang J. Comparison of dynamic balance ability in healthy university students according to foot shape. J. Phys. Ther. Sci., 2016; 28: 661-664. https://doi.org/10.1589/jpts.28.661

22.Zanevskyy IP, Nowak S. Balance control of the orthostatic body pose in physical education of students.
Physical Education of Students, 2020; 24(1): 63-70. https://doi.org/10.15561/20755279.2020.0108

23.DuyguA.Examining theEffect ofAcute Whole-BodyVibration on Static and Dynamic Balance in PhysicalEducation Students. Journal of Education and Learning, 2019; 8(5): 142-151. https://doi.org/10.5539/jel.v8n5p142

\section{Information about the authors:}

Jarosław Jaszczur-Nowicki; (Corresponding Author); http://orcid.org/0000-0001-5256-1406; j.jaszczur-nowicki@uwm.edu. pl; University of Warmia and Mazury in Olsztyn; Department of Tourism, Recreation and Ecology; Oczapowskiego 5, 10-719 Olsztyn, Poland.

Joanna Bukowska; http://orcid.org/0000-0003-0729-7292; joanna.bukowska@uwm.edu.pl; Department of Tourism, Recreation and Ecology; Oczapowskiego 5, 10-719 Olsztyn, Poland.

Dariusz Kruczkowski; http://orcid.org/0000-0002-2582-5661; dyrektor@olimpijczyk.gda.pl; Elbląg University of Humanities and Economics in Elbląg; ul. Lotnicza 2 82-300 Elbląg, Poland.

Michał Spieszny; http://orcid.org/0000-0002-9934-6911; michal.spieszny@awf.krakow.pl; Institute of Sport Sciences, Faculty of Physical Education and Sports, University of Physical Education, Krakow, Poland

Magdalena Pieniążek; https://orcid.org/0000-0003-2815-5867; pieniazek.mag@gmail.com; Department of Rehabilitation in Internal Diseases, Faculty of Rehabilitation, Bronisław Czech University School of Physical Education in Kraków, al. Jana Pawła II 78, 31-571 Kraków, Poland.

Grzegorz Mańko; https://orcid.org/0000-0002-9975-3074; mankofizjo@gmail.com; Faculty of Health Sciences, Department of Biomechanics and Kinesiology, Medical College (Collegium Medicum) of the Jagiellonian University in Kraków, Grzegórzecka 20, 31-531 Kraków, Poland.

\section{Cite this article as:}

Jaszczur-Nowicki J, Bukowska J, Kruczkowski D, Spieszny M, Pieniążek M, Mańko G. Analysis of students' foot pressure distribution on the ground, as well as their body balance before and after exercise. Physical Education of Students, 2020;24(4):194-204.

https://doi.org/10.15561/20755279.2020.0402

This is an Open Access article distributed under the terms of the Creative Commons Attribution License, which permits unrestricted use, distribution, and reproduction in any medium, provided the original work is properly cited http://creativecommons.org/licenses/by/4.0/deed.en

Received: 18.04.2020

Accepted: 28.05.2020; Published: 30.08.2020 